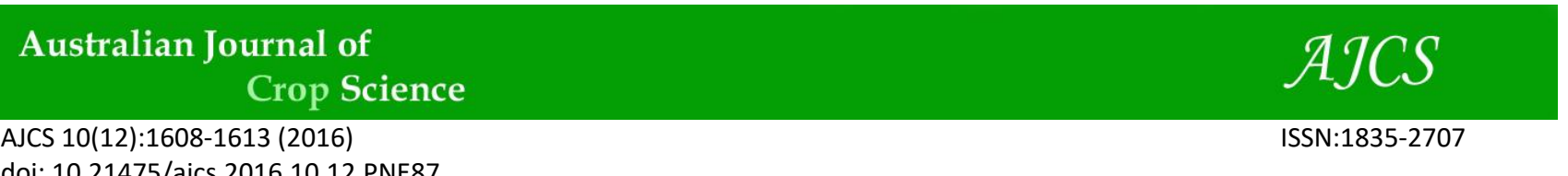

doi: 10.21475/ajcs.2016.10.12.PNE87

\title{
Variation in nitrogen uptake efficiency in upland rice landraces as influenced by $P$ fertilization
}

\author{
Adibah Mohd Amin ${ }^{1 *}$, Zaharah Abdul Rahman ${ }^{1}$, Mohamed Hanafi Musa ${ }^{1}$, Siti Nor Akmar Abdullah ${ }^{2}$ \\ ${ }^{1}$ Department of Land Management, Faculty of Agriculture, Universiti Putra Malaysia, 43400 Serdang, Selangor, \\ Malaysia \\ ${ }^{2}$ Department of Agricultural Technology, Faculty of Agriculture, Universiti Putra Malaysia, 43400 Serdang, \\ Selangor, Malaysia
}

*Corresponding author: adibahamin@upm.edu.my

\begin{abstract}
Upland rice are usually planted on infertile soils that have been eroded and degraded. The high fertilizer inputs to poor nitrogen (N) content soils can increase plant production but are neither economically viable nor sustainable. Hence, this study was focused on $\mathrm{P}$ fertilizers effects on $\mathrm{N}$ use efficiency (NUE) of five upland rice landraces which was conducted at Carey Island, Selangor. The study was evaluated using two phosphorus levels $(0$ and $100 \mathrm{~kg} \mathrm{P} / \mathrm{ha})$. A factorial experiment was conducted with four replications in randomized complete block design (RCBD). Ammonium sulphate fertilizer $\left[\left({ }^{15} \mathrm{NH}_{4}\right)_{2} \mathrm{SO}_{4}\right]$ with $1 \% \mathrm{~N}-15$ atom excess was applied as $\mathrm{N}$-labelled fertilizer at the rate of $150 \mathrm{~kg} \mathrm{~N} / \mathrm{ha}$. The source of $\mathrm{K}$ in the form of muriate of potash was applied also at the same rate. Destructive sampling was carried out at week 4,8 and 16 after transplanting and the NUE of the landraces were evaluated using isotope dilution technique. The P fertilization had no significant effect on NUE as well as on dry matter yield. These results suggested that $\mathrm{P}$ is not one of the limiting factors in plant growth and production as well as nitrogen use efficiency of these selected upland rice landraces. The dry matter yield and NUE were not significantly different among landraces at week 4 as the plants undergo their vegetative growth. These upland rice landraces showed significant differences in dry matter yield and nitrogen use efficiency at maturity stage (16 weeks). Landrace I showed significantly lower NUE compared to other landraces at week 16, while landrace III is the most efficient in utilizing nitrogen for production of dry matter.
\end{abstract}

Keywords: NUE, upland rice, ${ }^{15} \mathrm{~N}$, phosphorus, nitrogen.

Abbreviations: NUE_nitrogen use efficiency, N_nitrogen, P_phosphorus, CEC_cation exchange capacity, TSP_triple super phosphate, Ndff_nitrogen derived from fertilizer.

\section{Introduction}

Rice is the staple food for half the world's population. Malaysians consume about 2.2 million tonnes of rice annually (Hanim, 2009). Around 3 billion people of the world use rice as a basic food that provides 50 to $80 \%$ of their daily calories (Sohrabi et al., 2012). Globally, rice is cultivated on more than 150 million hectares, with an annual production of around 600 million tons (Guimaraes, 2009). Upland rice comprises eleven percent of global rice production and is cultivated on around 14 million hectares of land. Upland rice (Oryza sativa) refers to rice grown on both flat and sloping fields, that were prepared and seeded under dry conditions, and that depend on rainfall for moisture (Mae, 1997). Upland rice has a small role in total rice production but is a major source of food in some tropical countries (Thanh et al., 1999). Bangladesh, Indonesia, and Philippines are the areas that plant the most upland rice, but the yield is so low (about $1 \mathrm{t} /$ ha on average) (Musa et al., 2009; Reuveni, 2011).

In Malaysia, two types of rice are cultivated: wetland rice in Peninsular Malaysia (503,184 ha) and upland rice in Sabah and Sarawak $(165,888 \mathrm{ha})$. The average yield of upland rice ranges from 0.46 to $1.1 \mathrm{t} / \mathrm{ha}$., upland rice is usually cultivated for home consumption by rural people living in Sabah and Sarawak (Sohrabi et al., 2012). It is still an important agricultural activity for home consumption and sometimes the farmers sell their surplus to earn some money. However, the upland rice production has not been widely exploited for commercial production as its production is still dependent only on the nutrients in the soil (Wang et al., 2008; Musa et al., 2009). Nitrogen is one of the macro nutrients that is needed by all plants and it is one of the most yield limiting nutrients for upland rice production (Fageria et al., 2010). In some regions, phosphorus $(\mathrm{P})$ deficiencies can also limit the accumulation of crop biomass caused by a reduction in the partitioning of assimilates to the formation of leaf area, or a decrease of the efficiency with which the intercepted radiation is used for the production of above-ground biomass (Zubillaga et al., 2002). Several studies were conducted in understanding $\mathrm{P}$ effects. Excess $\mathrm{P}$ induced zinc and copper deficiencies in soybean (Payne et al., 1986), whereas $P$ deficiency in soil increased $\mathrm{N}$ concentration in rice shoot (Saleque et al., 1995) and had lower rice yield (Saleque et al., 1998). An optimum $P$ nutrition was found to increase the uptake and leaf concentrations of both $\mathrm{Mg}$ and calcium in wheat seedlings (Reinbott et al., 1991).

The research findings cited above indicated that the $\mathrm{P}$ nutrition status of a crop might affect its uptake of other elements. Considering these findings, we studied the effect of $\mathrm{P}$ on NUE of five upland rice landraces because little is known about the effect of phosphorus and nitrogen fertilization on the requirement of $\mathrm{N}$ of upland rice landraces. The genetic diversity of the upland landraces should be emphasized as a key to find a more superior cultivar in terms of nutrient uptake. The findings in identifying the landraces can be used to increase the current rice production, allowing 
more upland rice to be planted on hilly area with poor nutrient content and reducing the nutrient input/loss in a long run. Hence, the objectives of this study were 1) to determine the NUE of 5 upland rice landraces in the field and 2) to investigate the effects of phosphorus fertilization on nitrogen use efficiency of selected upland rice landraces under field conditions.

\section{Results and Discussions}

\section{Dry matter yield of selected upland rice landraces}

Landraces showed no significant effects on dry matter yield at week 4 and 8 . At week 16, there was significant differences on dry matter yield among landraces (Table 2). At week 16, Landrace III had the highest dry matter yield which was $2519.39 \mathrm{~g} / \mathrm{m}^{2}$ and it showed the same trend of having higher dry matter yield compared to other landraces at week 4 and 8 .

\section{Nitrogen derived from fertilizer (Ndff)}

At week 4, Landrace II had the highest percent Ndff and Landrace III had the lowest percent Ndff which was $31.54 \%$ and $22.82 \%$, respectively even though there was no significant difference between landraces and $\mathrm{P}$ fertilization (Table 3). At week 8 and 16, there was also no significant differences between landraces and $\mathrm{P}$ fertilization. Landrace III had the lowest percent Ndff which was $18.43 \%$ and $29.61 \%$ at week 8 and 16, respectively. However, despite the lower Ndff, landrace III had the highest NUE at week 16. Low Ndff but high NUE may indicate that it take up small amounts of $\mathrm{N}$ from fertilizer but utilize quite high amount of $\mathrm{N}$ in the plant. A study by Riga et al. (1980) found that the Ndff is related to the split fertilizer application schedule and significantly higher Ndff values had been found for the 3split dressings. In this particular study also, the fertilizer application was made in 3-split applications. The reason behind this effectiveness of split dressing was because nutrient supply and plant demand relationship (Chen et al., 2006).

\section{Nitrogen concentration}

Nitrogen concentration of upland rice landraces recorded a similar trend. There were not statistically different among the landraces at all weeks (Table 4). However, week 4 recorded nitrogen concentration between $3.04 \%$ and $3.51 \%$. At week 8 , these values decrease to $1.82 \%$ and $2.28 \%$. Nitrogen concentration at week 16 was between $0.97 \%$ and $1.14 \%$. This decrease in $\mathrm{N}$ concentration was caused by dilution effect. The dilution effect refers to the change in nutrient concentration as a function of time in plant growth or increase in biomass produced with time (Jarrell and Beverly, 1981). The dilution effect often has been found especially for $\mathrm{N}$ that young plants contain higher concentration than older plants. In this study also, nitrogen concentration showed decreasing trend from week 4 to week 16 for all landraces.

\section{$N$ yield}

The $\mathrm{N}$ yield refers to total $\mathrm{N}$ uptake of the plant per square meter. In this study, the total $\mathrm{N}$ uptake was not significantly affected by landraces at week 4 and 8 . At week 16 , the total $\mathrm{N}$ uptake were significantly affected by landraces (Table 5). This indicated that up until week 8 , all the landraces did not show enough difference in their total $\mathrm{N}$ uptake to significantly highlight the difference among landraces. However, at week 16, landrace I had the lowest total $\mathrm{N}$ uptake compared to landrace III.

\section{Fertilizer $N$ yield}

Fertilizer $\mathrm{N}$ yield is the $\mathrm{N}$ yield measured from labelled fertilizer that has been taken up by the crop. No significant differences were observed at week 4 and 8 after transplanting among the landraces. At week 16, landrace III has significantly higher fertilizer $\mathrm{N}$ yield compared to landrace I (Table 6). This indicated that, landrace III had incorporated more $\mathrm{N}$ from labelled fertilizer to the plant compared to other landraces.

\section{Evaluation of nitrogen use efficiency}

The results of nitrogen use efficiency (NUE) with Phosphorus fertilization and their interactions are shown in Table 7. The NUE describes the efficiency of $\mathrm{N}$ fertilizer utilization in crop production. For most plant species, NUE mainly depends on how plants extract inorganic nitrogen from the soil, assimilate nitrate and ammonium, and recycle organic nitrogen (Masclaux-Daubresse, et al., 2010). In this isotope labelling study, $\mathrm{N}$ recovered from fertilizer is also known as NUE. NUE had no significant effects amongst the landraces at the early stage (week 4). At this stage, the plants are undergoing the vegetative growth and similar efficiency in utilizing nitrogen from the fertilizer up until the reproductive growth stage (week 8). At 8 weeks after transplanting, landrace I had the highest NUE (33.59\%) compared to other landraces. At 16 weeks which was the maturity stage, the plants showed significant nitrogen use efficiency differences among landraces $(\mathrm{p} \leq 0.05)$. Landrace III had the highest NUE (52.59\%), while landrace I showed $27.50 \%$ NUE. This result suggested that the landrace III has used the supplied $\mathrm{N}$ fertilizer to produce higher dry matter more efficiently than landrace I as landrace III possess significantly higher DMY compared to landrace I. The others possible reasons why some landraces are more efficient in $\mathrm{N}$ utilization are probably cause by differing utilization on $\mathrm{N}$ already accumulated in the plant prior to anthesis, water use efficiency, forms of $\mathrm{N}$ uptake due to genotypic variability (Fageria, 2013).

\section{Phosphorus fertilization}

Phosphorus is important elements to plants as its application can promote root growth, enhance utilization of soil nutrients and water by plants, and finally increase crop yields (Gao et al., 1989; Li et al., 1995). In this experiment, the interaction between upland rice landraces and $\mathrm{P}$ fertilizer was not observed for all the parameters measured. Hence, the discussion will focus on the main effect of P fertilizer. NUE, dry matter yield and grain yield under the two different $\mathrm{P}$ levels recorded a similar trend. This also indicates that $\mathrm{P}$ fertilizer does not contribute to significant difference in the NUE and grain yield across all landraces. In this study, the soil contained abundant available P $(22.19 \mathrm{mg} / \mathrm{kg}$ Bray II extractable $\mathrm{P}$ ), and therefore there was no significant difference in NUE, DMY and grain yield between application and without application of $\mathrm{P}$ fertilizer for all the landraces, indicating that crops having no response to $\mathrm{P}$ fertilizer. Further application of $\mathrm{P}$ fertilizer has no significant effects to the plants. Although phosphorus is indispensable to plants, crop response to $\mathrm{P}$ fertilizers depends on soil available $\mathrm{P}$ as well as on crop species. In soil deficient in available P, crops generally have a good response to its application (Wang and $\mathrm{Li}, 2004$ ).

The results of this study is concurrent with the findings of other researcher who have reported that $\mathrm{P}$ fertilizers do not 
Table 1. Upland rice landraces and their origin.

\begin{tabular}{lc}
\hline Upland rice landraces & State of origin (Malaysia) \\
\hline Landrace I & Sabah \\
Landrace II & Pahang \\
Landrace III & Pahang \\
Landrace IV & Pahang \\
Landrace V & Pahang \\
\hline
\end{tabular}

Table 2. Dry matter yield at week 4,8 and 16 after transplanting.

\begin{tabular}{|c|c|c|c|c|c|c|c|c|c|}
\hline \multirow[b]{3}{*}{ Landraces } & \multicolumn{9}{|c|}{ DMY $(\mathrm{g} / \mathrm{m} 2)$} \\
\hline & \multicolumn{3}{|c|}{ WEEK 4} & \multicolumn{3}{|c|}{ WEEK 8} & \multicolumn{3}{|c|}{ WEEK 16} \\
\hline & 0 & 100 & $\begin{array}{c}\text { Means } \\
\text { landraces }\end{array}$ & 0 & 100 & $\begin{array}{c}\text { Means } \\
\text { landraces }\end{array}$ & 0 & 100 & $\begin{array}{c}\text { Means } \\
\text { landraces }\end{array}$ \\
\hline I & 21.68 & 16.68 & $19.18^{\mathrm{a}}$ & 584.21 & 501.75 & $542.98^{\mathrm{a}}$ & 1078.48 & 1289.44 & $1183.96^{\mathrm{a}}$ \\
\hline II & 27.88 & 17.88 & $22.88^{\mathrm{a}}$ & 482.88 & 427.14 & $455.01^{\mathrm{a}}$ & 1733.84 & 1368.76 & $1551.30^{\mathrm{ab}}$ \\
\hline III & 17.44 & 26.74 & $22.09^{\mathrm{a}}$ & 664.04 & 391.30 & $527.67^{\mathrm{a}}$ & 2317.00 & 2721.79 & $2519.39^{c}$ \\
\hline IV & 16.12 & 17.86 & $16.99^{\mathrm{a}}$ & 222.96 & 349.38 & $286.17^{\mathrm{a}}$ & 1888.92 & 1984.96 & $1936.94^{\mathrm{abc}}$ \\
\hline V & 18.66 & 17.92 & $18.29^{\mathrm{a}}$ & 450.62 & 107.51 & $279.06^{\mathrm{a}}$ & 1756.97 & 2983.61 & $2370.29^{\mathrm{bc}}$ \\
\hline Means P rates & $20.35^{\mathrm{a}}$ & $19.42^{\mathrm{a}}$ & & $480.94^{\mathrm{a}}$ & $355.42^{\mathrm{a}}$ & & $1755.04^{\mathrm{a}}$ & $2069.71^{\mathrm{a}}$ & \\
\hline
\end{tabular}

Table 3. Nitrogen derived from fertilizer at week 4,8 and 16 after transplanting.

\begin{tabular}{|c|c|c|c|c|c|c|c|c|c|}
\hline \multirow[b]{3}{*}{ Landraces } & \multicolumn{9}{|c|}{$\% \mathrm{NdfF}$} \\
\hline & \multicolumn{3}{|c|}{ WEEK 4} & \multicolumn{3}{|c|}{ WEEK 8} & \multicolumn{3}{|c|}{ WEEK 16} \\
\hline & 0 & 100 & $\begin{array}{c}\text { Means } \\
\text { landraces }\end{array}$ & 0 & 100 & $\begin{array}{c}\text { Means } \\
\text { landraces }\end{array}$ & 0 & 100 & $\begin{array}{c}\text { Means } \\
\text { landraces }\end{array}$ \\
\hline I & 30.34 & 24.76 & $27.55^{\mathrm{a}}$ & 34.95 & 28.77 & $31.86^{\mathrm{a}}$ & 38.13 & 34.14 & $36.13^{\mathrm{a}}$ \\
\hline II & 28.53 & 34.55 & $31.54^{\mathrm{a}}$ & 24.53 & 19.32 & $21.92^{\mathrm{a}}$ & 31.81 & 41.34 & $36.57^{\mathrm{a}}$ \\
\hline III & 25.57 & 18.99 & $22.28^{\mathrm{a}}$ & 24.32 & 12.55 & $18.43^{\mathrm{a}}$ & 29.74 & 29.48 & $29.61^{\mathrm{a}}$ \\
\hline IV & 32.49 & 29.14 & $30.58^{\mathrm{a}}$ & 30.47 & 22.21 & $26.34^{\mathrm{a}}$ & 29.31 & 29.90 & $29.60^{\mathrm{a}}$ \\
\hline $\mathrm{V}$ & 32.64 & 23.50 & $28.72^{\mathrm{a}}$ & 27.51 & 40.18 & $33.85^{\mathrm{a}}$ & 33.93 & 29.18 & $31.55^{\mathrm{a}}$ \\
\hline Means $P$ rates & $29.78^{a}$ & $26.33^{\mathrm{a}}$ & & $28.36^{\mathrm{a}}$ & $24.61^{\mathrm{a}}$ & & $32.58^{\mathrm{a}}$ & $32.81^{\mathrm{a}}$ & \\
\hline
\end{tabular}

Values with the same letter(s) are not significantly different according to the LSD Test at $\mathrm{P} \geq 0.05$.

Table 4. Nitrogen concentration at week 4,8 and 16 after transplanting.

\begin{tabular}{|c|c|c|c|c|c|c|c|c|c|}
\hline \multirow[b]{3}{*}{ Landraces } & \multicolumn{9}{|c|}{$\% \mathrm{~N}$} \\
\hline & \multicolumn{3}{|c|}{ WEEK 4} & \multicolumn{3}{|c|}{ WEEK 8} & \multicolumn{3}{|c|}{ WEEK 16} \\
\hline & 0 & 100 & $\begin{array}{l}\text { Means } \\
\text { landraces }\end{array}$ & 0 & 100 & $\begin{array}{l}\text { Means } \\
\text { landraces }\end{array}$ & 0 & 100 & $\begin{array}{l}\text { Means } \\
\text { landraces }\end{array}$ \\
\hline I & 3.48 & 3.43 & $3.45^{\mathrm{a}}$ & 1.82 & 2.00 & $1.91^{\mathrm{a}}$ & 0.97 & 0.99 & $0.98^{\mathrm{a}}$ \\
\hline II & 3.19 & 3.37 & $3.28^{\mathrm{a}}$ & 2.02 & 2.26 & $2.14^{\mathrm{a}}$ & 1.05 & 1.13 & $1.09^{\mathrm{a}}$ \\
\hline III & 3.51 & 3.30 & $3.40^{\mathrm{a}}$ & 2.30 & 1.82 & $2.06^{\mathrm{a}}$ & 1.14 & 1.13 & $1.13^{\mathrm{a}}$ \\
\hline IV & 3.38 & 3.34 & $3.36^{\mathrm{a}}$ & 2.28 & 2.03 & $2.16^{\mathrm{a}}$ & 0.89 & 1.11 & $1.00^{\mathrm{a}}$ \\
\hline V & 3.04 & 3.42 & $3.23^{\mathrm{a}}$ & 1.89 & 1.91 & $1.90^{\mathrm{a}}$ & 1.12 & 1.05 & $1.08^{\mathrm{a}}$ \\
\hline Means $P$ rates & $3.32^{\mathrm{a}}$ & $3.37^{\mathrm{a}}$ & & $2.06^{\mathrm{a}}$ & $2.00^{\mathrm{a}}$ & & $1.03^{\mathrm{a}}$ & $1.08^{\mathrm{a}}$ & \\
\hline
\end{tabular}

Values with the same letter(s) are not significantly different according to the LSD Test at $\mathrm{P} \geq 0.05$.

Table 5. Nitrogen yield at week 4,8 and 16 after transplanting.

\begin{tabular}{|c|c|c|c|c|c|c|c|c|c|}
\hline \multirow[b]{3}{*}{ Landraces } & \multicolumn{9}{|c|}{$\mathrm{N}$ yield $(\mathrm{g} / \mathrm{m} 2)$} \\
\hline & \multicolumn{3}{|c|}{ WEEK 4} & \multicolumn{3}{|c|}{ WEEK 8} & \multicolumn{3}{|c|}{ WEEK 16} \\
\hline & 0 & 100 & $\begin{array}{c}\text { Means } \\
\text { landraces }\end{array}$ & 0 & 100 & $\begin{array}{c}\text { Means } \\
\text { landraces }\end{array}$ & 0 & 100 & $\begin{array}{c}\text { Means } \\
\text { landraces }\end{array}$ \\
\hline I & 0.74 & 0.57 & $0.65^{\mathrm{a}}$ & 10.75 & 9.82 & $10.28^{\mathrm{a}}$ & 10.75 & 12.83 & $11.79^{\mathrm{a}}$ \\
\hline II & 0.88 & 0.61 & $0.75^{\mathrm{a}}$ & 10.13 & 9.76 & $9.95^{\mathrm{a}}$ & 18.05 & 14.99 & $16.52^{\mathrm{ab}}$ \\
\hline III & 0.60 & 0.86 & $0.73^{\mathrm{a}}$ & 15.24 & 7.29 & $11.27^{\mathrm{a}}$ & 28.92 & 31.32 & $30.12^{\mathrm{c}}$ \\
\hline IV & 0.55 & 0.57 & $0.56^{\mathrm{a}}$ & 5.14 & 6.37 & $5.75^{\mathrm{a}}$ & 17.15 & 21.62 & $19.39^{\mathrm{abc}}$ \\
\hline $\mathrm{V}$ & 0.57 & 0.62 & $0.59^{\mathrm{a}}$ & 7.75 & 6.81 & $7.28^{\mathrm{a}}$ & 17.88 & 31.31 & $24.60^{\mathrm{bc}}$ \\
\hline Means $P$ rates & $0.67^{\mathrm{a}}$ & $0.65^{\mathrm{a}}$ & & $9.80^{\mathrm{a}}$ & $8.01^{\mathrm{a}}$ & & $18.55^{\mathrm{a}}$ & $22.41^{\mathrm{a}}$ & \\
\hline
\end{tabular}

Values with the same letter(s) are not significantly different according to the LSD Test at $\mathrm{P} \geq 0.05$. 
Table 6. Fertilizer nitrogen yield at week 4,8 and 16 after transplanting

\begin{tabular}{|c|c|c|c|c|c|c|c|c|c|}
\hline \multirow[b]{3}{*}{ Landraces } & \multicolumn{9}{|c|}{ Fertilizer N yield $(\mathrm{g} / \mathrm{m} 2)$} \\
\hline & \multicolumn{3}{|c|}{ WEEK 4} & \multicolumn{3}{|c|}{ WEEK 8} & \multicolumn{3}{|c|}{ WEEK 16} \\
\hline & 0 & 100 & $\begin{array}{c}\text { Means } \\
\text { landraces }\end{array}$ & 0 & 100 & $\begin{array}{c}\text { Means } \\
\text { landraces }\end{array}$ & 0 & 100 & $\begin{array}{c}\text { Means } \\
\text { landraces }\end{array}$ \\
\hline I & 0.25 & 0.14 & $0.19^{\mathrm{a}}$ & 3.75 & 2.97 & $3.36^{\mathrm{a}}$ & 3.82 & 4.44 & $4.13^{\mathrm{a}}$ \\
\hline II & 0.22 & 0.24 & $0.23^{\mathrm{a}}$ & 1.98 & 1.77 & $1.87^{\mathrm{a}}$ & 5.27 & 6.20 & $5.73^{\mathrm{ab}}$ \\
\hline III & 0.15 & 0.16 & $0.16^{\mathrm{a}}$ & 3.29 & 0.76 & $2.03^{\mathrm{a}}$ & 7.07 & 8.71 & $7.89^{\mathrm{c}}$ \\
\hline IV & 0.13 & 0.16 & $0.15^{\mathrm{a}}$ & 1.58 & 6.37 & $1.61^{\mathrm{a}}$ & 4.79 & 5.58 & $5.19^{\mathrm{ab}}$ \\
\hline V & 0.20 & 0.13 & $0.17^{\mathrm{a}}$ & 2.06 & 2.99 & $2.52^{\mathrm{a}}$ & 5.59 & 8.55 & $7.07^{\mathrm{bc}}$ \\
\hline Means $P$ rates & $0.19^{\mathrm{a}}$ & $0.17^{\mathrm{a}}$ & & $9.80^{\mathrm{a}}$ & $8.01^{\mathrm{a}}$ & & $5.31^{\mathrm{a}}$ & $6.70^{\mathrm{a}}$ & \\
\hline
\end{tabular}

Table 7. Fertilizer nitrogen utilization at week 4,8 and 16 after transplanting.

\begin{tabular}{|c|c|c|c|c|c|c|c|c|c|}
\hline \multirow[b]{3}{*}{ Landraces } & \multicolumn{9}{|c|}{$\%$ FERT N utilization } \\
\hline & \multicolumn{3}{|c|}{ WEEK 4} & \multicolumn{3}{|c|}{ WEEK 8} & \multicolumn{3}{|c|}{ WEEK 16} \\
\hline & 0 & 100 & $\begin{array}{c}\text { Means } \\
\text { landraces }\end{array}$ & 0 & 100 & $\begin{array}{c}\text { Means } \\
\text { landraces }\end{array}$ & 0 & 100 & $\begin{array}{c}\text { Means } \\
\text { landraces }\end{array}$ \\
\hline I & 4.96 & 2.76 & $3.86^{\mathrm{a}}$ & 37.49 & 29.68 & $33.58^{\mathrm{a}}$ & 25.43 & 29.56 & $27.50^{\mathrm{a}}$ \\
\hline II & 4.36 & 4.83 & $4.59^{\mathrm{a}}$ & 19.82 & 17.66 & $18.73^{\mathrm{a}}$ & 35.14 & 41.32 & $38.23^{a b}$ \\
\hline III & 3.00 & 3.24 & $3.12^{\mathrm{a}}$ & 32.91 & 7.63 & $20.26^{\mathrm{a}}$ & 47.14 & 58.05 & $52.59^{c}$ \\
\hline IV & 2.68 & 3.27 & $3.02^{\mathrm{a}}$ & 15.83 & 16.38 & $16.10^{\mathrm{a}}$ & 31.92 & 37.22 & $34.57^{\mathrm{ab}}$ \\
\hline V & 4.09 & 2.59 & $3.44^{\mathrm{a}}$ & 20.63 & 29.85 & $25.24^{\mathrm{a}}$ & 37.24 & 57.02 & $47.13^{\mathrm{bc}}$ \\
\hline Means $\mathrm{P}$ rates & $3.87^{\mathrm{a}}$ & $3.38^{\mathrm{a}}$ & & $25.37^{\mathrm{a}}$ & $20.24^{\mathrm{a}}$ & & $35.37^{\mathrm{a}}$ & $44.63^{\mathrm{a}}$ & \\
\hline
\end{tabular}

contribute to increase yield in plant at soil $\mathrm{P}$ levels $>15$ $\mathrm{mg} / \mathrm{kg}$ (Hankinson et al., 2015). Another study done by Shehu et al., (2010) found that application of P significantly increased dry matter yields plant ${ }^{-1}$ but no significant increase in $\mathrm{N}$ uptake during $\mathrm{P}$ fertilization. Similar result was shown by Lajtha and Klein (1988) where they found that NUE was not significantly correlated with $\mathrm{P}$ supply rate in Larrea tridentate and they concluded that there was no evidence of significant interactions between $\mathrm{N}$ and $\mathrm{P}$ in Larrea tridentate. Reich and Schoettle (1998) found that NUE was not well correlated with PUE in white pine.

Contradictory to this, a study by Verde et al. (2013) in Kenya found that $\mathrm{P}$ fertilizer can improve $\mathrm{N}$ uptake but has no significant effect on $\mathrm{N}$ concentration in plant. However, the results showed that triple super phosphate alone cannot be a better solution for increased yield. Another study by Zubillaga et al., (2002) found that P fertilization increased the $\mathrm{N}$ use efficiency in sunflower which also contradicted to the findings of this study.

\section{Materials and Methods}

\section{Planting of upland rice, experimental design and treatments} Study site

This study was conducted in Carey Island, Selangor, Malaysia $\left(2.8667^{\circ} \mathrm{N}, 101.3667^{\circ} \mathrm{E}\right)$. The soils were classified as Selangor Series (Paramanathan, 2000) or Typic Endoaquept belonging to the Inceptisol order according to the USDA soil taxonomy (Soil Survey Staff, 2014), that was coarse loamy and isohyperthermic. The soils had following chemical properties before any nutrients treatments: $\mathrm{pH}_{(\mathrm{H} 2 \mathrm{O})}$ 5.8, total carbon (C) $1.69 \%$, total $\mathrm{N} 0.23 \%$, total exchangeable bases $1.29 \mathrm{cmol} / \mathrm{kg}$, cation exchange capacity (CEC) $9.53 \mathrm{cmol}_{(+)} / \mathrm{kg}$, extractable $\mathrm{P} 22.2 \mathrm{mg} / \mathrm{kg}$ and aluminium $(\mathrm{Al})$ saturation $53.1 \%$. Soil $\mathrm{pH}$ was measured in soil:water (1:2.5) extract using PHM210 Standard $\mathrm{pH}$ meter at $30^{\circ} \mathrm{C}$ (Benton, 2001). Total $\mathrm{N}$ in soil was determined by Kjeldahl digestion method (Bremner and Mulvaney, 1982). The $\mathrm{P}$ was extracted using Bray and Kurtz No. 2 extractants (Bray and Kurtz, 1945). Organic carbon was analysed using
Carbon Analyser (Benton, 2001). CEC of the soil was determined using the leaching method (Thomas, 1982).

\section{Planting materials}

Five upland rice landraces were selected for this experiment based on their origin as summarized in Table 1. The upland rice seeds were soaked in water at $40{ }^{\circ} \mathrm{C}$ for 10 minutes prior to placing them on wet cocopeat for an effective germination. After 14 days, all the seedlings were transplanted to the experimental plots.

\section{Treatments and experimental design}

The experiment layout was a factorial arrangement in a randomized complete block design (RCBD) with four replications. The treatment consisted of 5 upland rice landraces in 2 nutrient levels; $\mathrm{N}$ input coupled with and without $\mathrm{P}$ input $\left(150 \mathrm{~kg} \mathrm{~N} \mathrm{ha}^{-1}+0 \mathrm{~kg} \mathrm{P} \mathrm{ha}^{-1}\right.$ and $150 \mathrm{~kg} \mathrm{~N} \mathrm{ha}^{-}$ ${ }^{1}+$ at $\left.100 \mathrm{~kg} \mathrm{P} \mathrm{ha}^{-1}\right)$. Each treatment plot measured an area of $4 \mathrm{~m}^{2}(2 \mathrm{~m} \times 2 \mathrm{~m})$ with a total of 40 plots. Destructive sampling was carried out at $4^{\text {th }}, 8^{\text {th }}$ and $16^{\text {th }}$ weeks after planting. For $\mathrm{N}$ application, a $150 \mathrm{~kg} \mathrm{~N}^{-1}$ in ammonium sulphate was split applied at the rate of $50 \mathrm{~kg} \mathrm{~N} \mathrm{ha}^{-1}$ at 0,4 and 8 weeks intervals after transplanting. In terms of ${ }^{15} \mathrm{~N}$ enriched-N application, the plot was divided into two regions; where labelled ammonium sulphate was applied to the innercentre $1 \mathrm{~m}^{2}$ plot, and unlabelled ammonium sulphate $\left(\mathrm{NH}_{4} \mathrm{SO}_{4}\right)$ was applied to the rest of the outer plot. The ${ }^{15} \mathrm{~N}$ source used was ${ }^{15} \mathrm{~N}$ labelled ammonium sulphate $\left[{ }^{15}\left(\mathrm{NH}_{4}\right)^{2} \mathrm{SO}_{4}\right]$ with $1 \%{ }^{15} \mathrm{~N}$ atom excess. For $\mathrm{P}$ application, $100 \mathrm{~kg} \mathrm{P} \mathrm{ha}^{-1}$ as Triple Super Phosphate (TSP) was applied only once at 0 week of transplant for the plot with $\mathrm{P}$ input. In terms of other nutrients, a $150 \mathrm{~kg} \mathrm{~K} \mathrm{ha}^{-1}$ as Muriate of Potash was split applied at the rate of $50 \mathrm{~kg} \mathrm{~K} \mathrm{ha}^{-1}$ at 0,4 and 8 weeks after transplanting.

\section{Destructive sampling}

Plant parameter was collected by carrying out destructive sampling at $4^{\text {th }}, 8^{\text {th }}$ and $16^{\text {th }}$ weeks after transplanting. At the 
$4^{\text {th }}$ and $8^{\text {th }}$ week after transplanting, only the shoot of the rice plants were collected. Grains were collected only at $16^{\text {th }}$ week of transplanting as well as the shoot. All shoot samples were subjected to $70{ }^{\circ} \mathrm{C}$ oven drying until constant weight was achieved. The dry weights of the samples were recorded using an analytical balance.

\section{Determination of Total Nitrogen and ${ }^{15} \mathrm{~N}$ analysis}

The ratio on ${ }^{15} \mathrm{~N} /{ }^{14} \mathrm{~N}$ isotope were determined using emission spectrophotometer, NOI-6 (Fisher Analyzer Instruments, Germany) Nuclear Malaysia laboratory. The percentage of $\mathrm{N}$ derived from fertilizer (\%NdFF) was calculated, based on the isotope dilution technique (IAEA, 1983). The performance of the landraces in taking up the $\mathrm{N}$ fertilizer was evaluated by comparing total $\mathrm{N}$ uptake derived from labelled fertilizer (Fertilizer $\mathrm{N}$ yield) as well as the NUE (Fertilizer $\mathrm{N}$ utilization).

\section{Statistical analysis}

ANOVA was used for data analysis and mean comparison was made using least significant difference (LSD) at $\mathrm{P} \leq 0.05$ to determine the significant difference among landraces. Statistical procedure was made by using the Statistical Analysis System package version 9.1.

\section{Conclusion}

The NUE involves complex mechanism. This study revealed that the P fertilization had no significant effect on NUE of these upland rice landraces, and may suggest that the $P$ concentration in the soil at planting time is sufficient for upland rice planting. Further addition of $\mathrm{P}$ fertilizer has no effect on plant as they had enough from soil. Low Ndff but high NUE may indicate that it take up small amounts of $\mathrm{N}$ from fertilizer but assimilate quite high amount of $\mathrm{N}$ in the plant. The ${ }^{15} \mathrm{~N}$ isotope labelling technique could provide a better insight into nitrogen uptake efficiencies in upland rice.

\section{Acknowledgement}

We wish to thank Universiti Putra Malaysia for providing the laboratory facilities. We also greatly appreciate to Ms Zabedah Tumirin (Universiti Putra Malaysia) and Ms Latifah Nordin (Nuclear Agency Malaysia) for their technical assistance that makes this work possible. The editorial corrections made by Dr. Tan Ngai Paing from our laboratory is highly appreciated.

\section{References}

Benton JJ (2001) Laboratory guide for conducting soil tests and plant analysis. CRC Press LLC. USA.

Bray RH, Kurtz LT (1945) Determination of total, organic, and available forms of phosphorus in soils. Soil Science. 59(1):39-46.

Bremner JM, Mulvaney CS (1982) Nitrogen-Total. In: Methods of soil analysis. Agron. No. 9, Part 2: Chemical and microbiological properties, 2nd ed. Amer. Soc. Agron. Madison, WI, USA. 595-624.

Chen X, Zhang F, Römheld V, Horlacher D, Schulz R, Böning-Zilkens M, Wang P, Claupein W (2006) Synchronizing $\mathrm{N}$ supply from soil and fertilizer and $\mathrm{N}$ demand of winter wheat by an improved Nmin method. Nutrient Cycling in Agroecosystems. 74(2):91-98.
Fageria NK, de Morais OP and dos Santos AB (2010) Nitrogen use efficiency in upland rice genotypes. J Plant Nutr. 33:1696-1711.

Fageria NK (2013) Mineral nutrition of rice. CRC Press.

Gao ZM, Zhang YD, Zhang DY, Shi RH, Zhang MF (1989) Effects of N, P and $\mathrm{K}$ on the accumulation of nitrate and the activity of nitrate reductase and superoxidase in leafy vegetables. Acta Hort Sin. 16:293-298.

Guimaraes EP (2009) Rice breeding. In: Cereals (pp. 1-28). Springer US.

Hanim A. Malaysia on track to meet rice target. The Star Online. http://biz.thestar.com.my. 2009 February 10; Accessed on $25^{\text {th }}$ March 2009.

Hankinson MW, Lindsey LE, Culman SW (2015) Effect of planting date and starter fertilizer on soybean grain yield. Crop Forage Turfgrass Manage. 1(1).

IAEA (1983) A guide to the use of nitrogen-15 and radioisotopes in studies of plant nutrition: calculations and interpretation of data: IAEA TECDOC-288, Vienna, Austria.

Jarrell WM, Beverly RB (1981) The dilution effect in plant nutrition studies. Adv Agron. 34(1):197-224.

Lajtha K, Klein M (1988) The effect of varying nitrogen and phosphorus availability on nutrient use by Larreatridentata, a desert evergreen shrub. Oecologia. 75(3):348-353.

Li SQ, Li SX, Tian XH (1995) Interaction effects of water and fertilizers on wheat yields and fertilizer efficiency. The Principle of Relationship between Fertilizer and Water of Dry Farming Land and Its Regulation Technology. 246262.

Masclaux-Daubresse C, Daniel-Vedele F, Dechorgnat J, Chardon F, Gaufichon L, Suzuki A (2010) Nitrogen uptake, assimilation and remobilization in plants: challenges for sustainable and productive agriculture. Ann Bot. mcq028.

Musa MH, Azemi H, Juraimi AS, TengkuMuda MM (2009) Upland rice varieties in Malaysia: agronomic and soil physico-chemical characteristics. Pertanika J Trop Agric Sci. 32(3):225-246.

Paramanantha S (2000) Soils of Malaysia: their characteristics and identification, Volume 1. Academy of Sciences Malaysia.

Payne GG, Sumner ME, Plank CO (1986) Yield and composition of soybeans as influenced by soil $\mathrm{pH}$, phosphorus, zinc, and copper 1. Communications in Soil Science Plant Analysis. 17(3):257-273.

Reich PB, Schoettle AW (1988) Role of phosphorus and nitrogen in photosynthetic and whole plant carbon gain and nutrient use efficiency in eastern white pine. Oecologia. 77(1):25-33.

Reinbott TM, Blevins DG (1991) Phosphate interaction with uptake and leaf concentration of magnesium, calcium, and potassium in winter wheat seedlings. Agron J. 83(6):10431046.

Reuveni E (2011) The genetic background effect on domesticated species: a mouse evolutionary perspective. Sci World J. 11:429-436.

Riga A, Fischer V, Van Praag HJ (1980) Fate of fertilizer nitrogen applied to winter wheat as $\mathrm{Na}^{15} \mathrm{NO}_{3}$ and $\left({ }^{15} \mathrm{NH} 4\right)_{2} \mathrm{SO}_{4}$ studied in microplots through a four-course rotation: 1. Influence of fertilizer splitting on soil and fertilizer nitrogen. Soil Sci. 130(2):88-99.

Saleque MA, Kirk GJD (1995) Root-induced solubilization of phosphate in the rhizosphere of lowland rice. New Phytol. 325-336. 
Saleque MA, Abedin MJ, Panaullah GM, Bhuiyan NI (1998) Yield and phosphorus efficiency of some lowland rice varieties at different levels of soil-available phosphorus. Communications in Soil Science Plant Analysis. 29(19-20):2905-2916.

Shehu HE, Kwari JD, Sandabe MK (2010) Effects of N, P and $\mathrm{K}$ fertilizers on yield, content and uptake of N, P and K by sesame (Sesamum indicum). Int J Agric Biol. 12(6):845850.

Sohrabi M, Rafii MY, Hanafi MM, SitiNorAkmar A, Latif MA (2012) Genetic diversity of upland rice germplasm in Malaysia based on quantitative traits. Sci World J.

Soil Survey Staff (2014). Keys to soil taxonomy, 12th ed. U.S. Department of Agriculture, Natural Resources Conservation Service, Washington, D.C.

Thanh ND, Zheng HG, Dong NV, Trinh LN, Ali ML, Nguyen HT (1999) Genetic variation in root morphology and microsatellite DNA loci in upland rice (Oryza sativa L.) from Vietnam. Euphytica. 105(1):53-62.
Thomas GW (1982) Exchangeable cations. In: Page AL, Miller RH, Keeny DR (Eds.) Methods of soil analyis, part 2, ASA-SSSA, Madison WI.

Verde BS, Danga BO, Mugwe JN (2013) Effects of manure, lime and mineral $\mathrm{P}$ fertilizer on soybean yields and soil fertility in a humic Nitisols in the central highlands of Kenya. Int J Agric Science Res. 2:283-291.

Wang $\mathrm{Y}$, Zhu B, Shi $\mathrm{Y}$ and $\mathrm{Hu} \mathrm{C}$. Effects of nitrogen fertilization on upland rice based on pot experiments. (2008). Communications in Soil Science and Plant Analysis. 39(11):1733-1749.

Wang Z, Li S (2004) Effects of nitrogen and phosphorus fertilization on plant growth and nitrate accumulation in vegetables. J Plant Nutr. 27(3):539-556.

Zubillaga MM, Aristi JP, Lavado RS (2002) Effect of phosphorus and nitrogen fertilization on sunflower (Helianthus annus L.) nitrogen uptake and yield. J Agron Crop Sci. 188(4):267-274 